\title{
Dissatisfaction with body image and associated factors in adult women
}

\section{Insatisfação com a imagem corporal e fatores associados em mulheres adultas}

\section{A B S T R A C T}

\section{Objective}

To associate body image with sociodemographic profile, lifestyle, anthropometry and health conditions in adult women.

\section{Methods}

Prevalence study, conducted in a probabilistic cluster sample ( $n=35$ Primary Education Schools) conducted in 2016 with 633 teachers. Sociodemographic characteristics were evaluated; morbidities, anthropometric variables; subjective health issues; lifestyle and self-reported morbidities.

\section{Results}

The prevalence of body image dissatisfaction was $48.7 \%$. There was a greater chance of dissatisfaction among older women who have children, unsatisfactory lifestyle, are overweight, with poor health/poor self-perception of health, and the presence of depressive symptoms. Women who had a poor lifestyle had a four-fold greater chance of dissatisfaction with body appearance (Odds Ratio=4.193) than women who had a satisfactory lifestyle.

1 Universidade Estadual de Montes Claros, Centro de Ciências Biológicas e da Saúde, Departamento de Educação Física. Montes Claros, MG, Brasil.

2 Universidade Estadual de Montes Claros, Centro de Ciências Biológicas e da Saúde, Programa de Pós-Graduação em Ciências da Saúde. Av. Cula Mangabeira, n. 562, Santo Expedito, 39401-002, Montes Claros, MG, Brasil. Correspondence to: NSS SILVA. E-mail: <nayrasusy@hotmail.com>.

3 Universidade Estadual de Montes Claros, Centro de Ciências Biológicas e da Saúde, Programa de Pós-Graduação em Cuidados Primários em Saúde. Montes Claros, MG, Brasil.

How to cite this article

Mota VEC, Haikal DS, Magalhães TA, Silva NSS, Silva RRV. Dissatisfaction with body image and associated factors in adult women. Rev Nutr. 2020;33:e190185. https://doi.org/10.1590/1678-9865202033e190185 


\section{Conclusion}

The results revealed that almost half of the adult women surveyed in this study reported dissatisfaction with their body image. This outcome indicates the need for interventions and program implementation related to body image dissatisfaction among women.

Keywords: Body image. Lifestyle. Nutritional status. Women's health.

\section{RE S U M O}

\section{Objetivo}

Esta pesquisa buscou associar imagem corporal com perfil sociodemográfico, estilo de vida, antropometria e condições de saúde em mulheres adultas.

\section{Métodos}

Um estudo de prevalência foi conduzido em uma amostra probabilistica por conglomerados ( $n=35$ Escolas da Educação Básica de Ensino), no ano de 2016, com 633 professoras. Foram avaliadas características sociodemográficas, morbidades, variáveis antropométricas, questões subjetivas em saúde, estilo de vida e morbidades autorreferidas.

\section{Resultados}

A prevalência de insatisfação com a imagem corporal foi de 48,7\%. Houve maior chance de insatisfação entre as mulheres com maior idade, filhos, estilo de vida insatisfatório, acima do peso, autopercepção ruim/péssima de sua saúde e presença de sintomas depressivos. Mulheres que apresentaram estilo de vida insatisfatório tiveram probabilidade quatro vezes maior de insatisfação com a aparência corporal (Odds Ratio=4,193) do que as com estilo de vida satisfatório.

\section{Conclusão}

Os resultados revelaram que quase metade das mulheres adultas pesquisadas neste estudo relatou ter insatisfação com a imagem corporal. Esses resultados indicam a necessidade de intervenções e de implementação de programas relacionados à insatisfação com a imagem corporal entre as mulheres.

Palavras-chave: Imagem corporal. Estilo de vida. Estado nutricional. Saúde da mulher.

\section{NTRODUCTION}

Body image is defined by aspects such as mental representations of size, appearance, body shape and is influenced by cultural, social, neurological and psychological factors [1], in addition to cognitive processes related to beliefs [2].

The term "body image" is the self-portrait that people imagine of their physical appearance and of their bodies [3] and the result of what the individual sees in the mirror added to her experience. It is a phenomenon that encompasses motor, cognitive, environmental and socio-cultural aspects [4]. Body Dissatisfaction (BD) affects mainly women. National [5-8] and international [9-11] studies point to a high prevalence of $\mathrm{BD}$ among adult women. Among the reasons that explain the high degree of $\mathrm{BD}$ in the female population are social demands and the strong influence of the media for seeking the perfect body [12-14].

The exposure of beautiful bodies by the media has been determining in the last decades, a compulsion for seeking the perfect body [15]. Some authors believe in the existence of a strong cultural trend that considers a thin body as being the ideal for women's social acceptance, so that there is a relationship between this social pressure to be slim and BD $[4,16,17]$. Many changes have occurred over time about the concept of a healthy and beautiful body; the cult of this body image is now a practice associated with power, beauty and social mobility [18]. 
The body image changes during the course of life due to emotional, synesthetic and proprioceptive experiences, in addition to visual stimuli and can be understood as a subjective mental representation of the physical appearance about experiences and concepts that the person has about her body [19]. The objective of achieving a perfect body negatively affects the perception of body image, especially in people with overweight and obesity, in which comparison between the actual weight and the target weight can trigger or potentiate depression symptoms in addition to negatively interfering with the treatment of obesity, since it affects behavior, mental well-being and quality of life [20].

In Brazil, dissatisfaction with body image has not been deeply studied. The studies target especially adolescents and university students, with little focus in adult women [5]. In this framework, the present study aims to associate body image with sociodemographic profile, lifestyle, anthropometry and health conditions in adult women.

\section{METHODS}

This study is part of the ProfSMoc Project - "Chronic Health Conditions and Associated Factors among Teachers from the Montes Claros, MG State Public School System: Population-based Study". This is an epidemiological, cross-sectional study carried out with elementary and high school teachers. Montes Claros is an urban municipality in the north of the State of Minas Gerais and has characteristics of a regional capital, with an estimated total population of 402,027 inhabitants (2017) [21].

The population was composed of basic education (elementary and high school) teachers from the state's public school system of the Municipality that at the time of the study retained 1,851 teachers. The sample was probabilistic by conglomerate in a single stage (schools) and 35 schools were drawn by Probability Proportional to Size (PPS), within a total of 49 state schools in the urban area of the municipality. The number of school teachers was the parameter considered as a reference for the PPS draw. The estimated minimum sample included 630 teachers, considering a finite population, $50 \%$ prevalence of the event of interest, $95 \%$ confidence level, $5 \%$ tolerable error and deff $=2.0$. Additionally, 10\% was added to compensate for possible losses.

All teachers associated with these schools and who had been teaching for at least one year were called to participate. Teachers deviating from teaching function or on sick leave for any reason were excluded. Data collection took place in the period from March to December 2016 in three stages: in the first stage, there was the initial contact with the school principals to introduce the project, consent of the institution and scheduling of the meeting with the teachers; in the second stage, which occurred at the beginning of the Module II meeting (pedagogical meeting included in the teaching time load), the teachers were made aware and invited to participate. Teachers who agreed to participate received self-administered questionnaires and, subsequently, a new date was scheduled to conduct the third stage, that is, collection and verification of the completed questionnaires and a physical evaluation.

For this study, only female teachers' data was considered. Women constituted $83 \%$ of the total sample investigated. The dependent variable adopted was BD, obtained through the following question: "As for the appearance of your body, you are". The response options followed the Likert scale with five categories (Very Satisfied; Satisfied; Indifferent; Dissatisfied and Very Dissatisfied), which were later dichotomized into: "Satisfied", with the options "Very Satisfied; Satisfied and 
Indifferent" vs "Unsatisfied", which included the options "Unsatisfied and Very Dissatisfied", the latter being the category of interest tested. The following independent variables were considered, grouped into four thematic blocks.

Sociodemographic Profile: Age (in years), Marital Status (Single; Married/Common-Law marriage and Divorced/Widowed), Social Class (Class A; Class B; Classes C/D/E), Self-declared Skin Complexion (White/Yellow; Black/Mulatto/Indigenous) and Children (No; Yes). The age variable was maintained according to its discrete numerical nature, as it was collected. Social class was assessed using the Brazil Economic Evaluation Criterion 2015 of the Brazilian Association of Research Companies, adopted to estimate the permanent income of families. The final score of the Social Class, as well as its categorization, followed the recommendations specific to the instrument [22].

Lyfe Style: it includes variables related to the "Fantastic Lifestyle", a standardized questionnaire that explores the physical, psychological and social components of lifestyle. The version of the instrument validated in Brazil was adopted [23]. The origin of the word "fantastic" comes from the acronym FANTASTIC, which represents the letters of the names of the nine domains (in English) in which

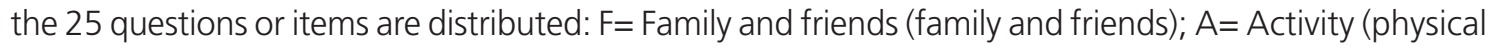
activity); $\mathrm{N}=$ Nutrition; $\mathrm{T}=$ Tobacco \& toxics (smoke and drugs); $\mathrm{A}=$ Alcohol; $\mathrm{S}=$ Sleep, seatbelts, stress, safe sex (sleep, seat belt, stress and safe sex); T= Type of behavior (behavior pattern; behavior pattern A or B); I= Insight (introspection); C= Career (work; satisfaction with the profession). It is a self-administered instrument that considers the behavior of individuals during the previous month and which results allow to determine the association between lifestyle and health. The questions are arranged in the form of a Likert scale in which 23 variables have five answer alternatives and two are dichotomous. The sum of all points allows reaching a total score that classifies individuals into five categories, which are: "Excellent" (85 to 100 points), "Very good" (70 to 84 points), "Good" (55 to 69 points) points), "Regular" (35 to 54 points) and "Needs improvement" (0 to 34 points). In the present study, the variables were categorized as "Satisfactory" Lifestyle (excellent, very good or good) vs "Inadequate" (regular or needs improvement).

Anthropometry: Anthropometric data were collected during the physical evaluation carried out in each school that was drawn, on the day the questionnaires were given back by the teachers. These procedures were performed in accordance with the recommendations of the World Health Organization (WHO) [24], complying with standardized procedures and biosafety rules were complied with. All evaluators were properly trained and calibrated and reached satisfactory intra- and inter-examiner agreement (weighted Kappa above $81 \%$ and Intraclass Correlation Coefficient above 0.85). The measurements were all repeated twice, using the mean of the measurements as the final result. The anthropometric measurements were: Waist Circumference (Normal; Large) that classified women without abdominal obesity with a waist circumference of up to $88 \mathrm{~cm}$ and with abdominal obesity above $88 \mathrm{~cm}$. The Body Mass Index (BMI) (Normal; Overweight; Obese), was calculated using the formula: $\mathrm{BMI}=$ weight $(\mathrm{kg}) /$ height $^{2}(\mathrm{~m})$ and classified with cutoff points established by the WHO, as follows: below $24.9 \mathrm{~kg} / \mathrm{m}^{2}$ normal, $25 \mathrm{~kg} / \mathrm{m}^{2}$ to $29.9 \mathrm{~kg} / \mathrm{m}^{2}$ overweight and $\geq 30 \mathrm{~kg} / \mathrm{m}^{2}$ obesity [24]. Teachers' weight was assessed using a calibrated digital scale (Digital Magna 150kg, G Tech Ltda ${ }^{\circledR}$, São Paulo, SP) to the nearest $0.1 \mathrm{~kg}$. Height was measured with the aid of an individual flat-base stadiometer and height-leveling apparatus functioning as a square. The Percentage of Body Fat \%BF (Normal; High), was obtained using bioimpedance, a method that estimates the volume of water in the body in accordance with the resistance of electric current of low amplitude (500-800mA) and high frequency $(50 \mathrm{kHz})$. A Bodystat ${ }^{\circledR}$ equipment, line 1.500 , a device with tetrapolar frequency 
and gel electrodes for electrocardiogram (Lectec Corporation ${ }^{\circledR}$, USA) was used. The measurement protocol followed Paiva's et al. protocol [25]. High BF\% was considered with values above 30\%.

Health Conditions: Self-perceived Health (Excellent/Good; Regular; Bad/Nery Bad), Depressive Symptoms (No; Yes), Menopause (No; Yes), High Cholesterol (No; Yes) and Diabetes (No; Yes). For self-perceived health, the following question was used: "Do you currently classify your health as?" (Excellent/Good; Regular and Bad/Poor). The presence of depressive symptoms was assessed using the Beck Depression Inventory [26], an instrument composed of 21 questions, which are scored from 0 to 3 points and allow a maximum score of 63 points, in which 11 or less points indicate no depressive symptoms and above 11 points presence of depressive symptoms. In this study, the variable "Depressive Symptoms" was dichotomized (Absent; Present). For the menopause variable, the following question was applied: "Are you in menopause?" The presence of high cholesterol and diabetes was self-reported, through the following questions: "Has any health professional ever told you that you have high cholesterol?" (No; Yes). "Has any health professional ever told you that you have Diabetes?" (No; Yes) [27].

The data were typed in duplicate, tabulated, audited and analyzed with the aid of the Statistical Package for Social Sciences (SPSS ${ }^{\circledR}$ ), version 18.0 [28]. In conducting the descriptive analyses, absolute and relative frequencies of the categorical variables and the mean and standard deviation of the numerical variable "age" were estimated. Correction was performed according to the design effect. To that effect, each teacher was associated with a weight, which corresponded to the inverse of its probability of inclusion in the sample and this correction promoted a difference in the prevalence estimate. Probability was estimated in PPS of the schools, that is, proportional to the number of teachers and the non-response rate was taken into account.

Sequentially, bivariate analyses were conducted using the Pearson's Chi-Square Test and the T-Test. In this analysis, all variables that revealed a descriptive level below $20 \%(p<0.2)$ were selected to initially compose the multiple model. In the multiple models, Binary Logistic Regression was adopted. The models were manually adjusted keeping, in the final model, only variables with a descriptive level below $5 \%(p<0.05)$. Odds Ratio (OR) was estimated, as well as its $95 \%$ confidence interval and descriptive level. The quality of the model fit was assessed by the descriptive level of the Hosmer and Lemeshow test, as well as by the Coefficient of determination (Pseudo $R^{2}$ ).

The ProfSMoc Project was approved and recommended by the Secretaria Regional e Estadual de Educação (Regional and State Department of Education of Montes Claros, Minas Gerais, Brasil). The project complied with the ethical principles of the Resolution of the Conselho Nacional de Saúde (National Health Council) n. 466/2012 and was approved by the Comitê de Ética em Pesquisa (Research Ethics Committee), Universidade Estadual de Montes Claros (State University of Montes Claros), under n. 1,293.458. All participating teachers received and signed the Free and Informed Consent Form. Teachers with suspected physical and/or psychological ailments were duly referred to the services that are partners in the project.

\section{RES U L T S}

Out of the 760 participating teachers, 127 were excluded because they were male. Thus, this study considered 633 female participants. The average age of the women studied was 40.98 years (Standard Deviation $(S D)=9.36$ ) and more than $65.0 \%$ were single, with approximately $60.0 \%$ falling into social class B. Regarding the BD variable, $48.7 \%$ (308) of the women participating in the 
study were dissatisfied with their body image. In the bivariate analysis, the following variables had a descriptive level of less than $20.0 \%$ and were selected for multiple analyses: age, marital status, children, lifestyle, waist circumference, BMI, body fat percentage, self-perceived health, depressive symptoms, menopause and cholesterol Table 1.

Table 1. Body satisfaction according to sociodemographic profile, lifestyle, anthropometry and health conditions among elementary and high school teachers from the State public schools network of Montes Claros, MG, Brazil, 2016.

1 of 2

\begin{tabular}{|c|c|c|c|c|c|c|c|}
\hline \multirow{2}{*}{ Variables } & \multicolumn{2}{|c|}{$\mathrm{n}=633(\%)$} & \multicolumn{2}{|c|}{ Satisfied } & \multicolumn{2}{|c|}{ Unsatisfied } & \multirow{2}{*}{$p$} \\
\hline & $\mathrm{n}$ & $\%$ & $n$ & $\%$ & $\mathrm{n}$ & $\%$ & \\
\hline \multicolumn{8}{|l|}{ Sociodemographic Profile } \\
\hline Age (in years) & & & \multicolumn{2}{|c|}{$( \pm S D)=41.5(9.7)$} & \multicolumn{2}{|c|}{$( \pm S D)=40.4(8.9)$} & $0.153^{* *}$ \\
\hline \multicolumn{8}{|l|}{ Marital Status } \\
\hline Single & 414 & 64.5 & 202 & 48.8 & 212 & 51.2 & \\
\hline Married/C.L. Marriage & 143 & 23.8 & 86 & 60.1 & 57 & 39.9 & $0.057^{* *}$ \\
\hline Divorced/Widowed & 76 & 11.7 & 37 & 48.7 & 39 & 51.3 & \\
\hline \multicolumn{8}{|l|}{ Social Class* } \\
\hline Class A & 72 & 11.3 & 40 & 55.6 & 32 & 44.4 & \\
\hline Class B & 368 & 59.7 & 184 & 50.0 & 184 & 50.0 & 0.632 \\
\hline Class C/D/E & 182 & 29.0 & 96 & 52.7 & 86 & 47.3 & \\
\hline \multicolumn{8}{|l|}{ Skin Color ${ }^{*}$} \\
\hline White/yellow & 203 & 30.8 & 110 & 54.2 & 93 & 45.8 & 0.339 \\
\hline Black/brown/indigenous & 429 & 69.2 & 215 & 50.1 & 214 & 49.9 & \\
\hline \multicolumn{8}{|l|}{ Children } \\
\hline No & 173 & 27.4 & 103 & 59.5 & 70 & 40.5 & $0.011^{* *}$ \\
\hline Yes & 460 & 72.6 & 222 & 48.3 & 238 & 51.7 & \\
\hline \multicolumn{8}{|l|}{ Lifestyle* $^{*}$} \\
\hline Satisfactory & 571 & 92.4 & 310 & 54.3 & 261 & 45.7 & $0.000^{* *}$ \\
\hline Inadequate & 45 & 7.6 & 4 & 8.9 & 41 & 91.1 & \\
\hline \multicolumn{8}{|l|}{ Anthropometry } \\
\hline \multicolumn{8}{|l|}{ Waist Circumference ${ }^{*}$} \\
\hline Normal & 505 & 84.6 & 289 & 57.2 & 216 & 42.8 & $0.000^{* *}$ \\
\hline Large & 93 & 15.4 & 21 & 22.6 & 72 & 77.4 & \\
\hline \multicolumn{8}{|l|}{$\mathrm{BMI}^{*}$} \\
\hline Normal & 292 & 48.3 & 193 & 66.1 & 99 & 33.9 & \\
\hline Overweight & 202 & 35.1 & 96 & 47.5 & 106 & 52.5 & $0.000^{* *}$ \\
\hline Obese & 97 & 16.6 & 18 & 18.6 & 79 & 81.4 & \\
\hline \multicolumn{8}{|l|}{ Body Fat Percentage* } \\
\hline Normal & 44 & 8.2 & 33 & 75.0 & 11 & 25.0 & $0.001^{* *}$ \\
\hline High & 550 & 92.8 & 274 & 49.8 & 276 & 50.2 & \\
\hline \multicolumn{8}{|l|}{ Health Conditions } \\
\hline \multicolumn{8}{|l|}{ Self-perceived Health } \\
\hline Excellent/Good & 411 & 65.9 & 263 & 64.0 & 148 & 36.0 & \\
\hline Regular & 185 & 28.5 & 56 & 30.3 & 129 & 69.7 & $0.000^{* *}$ \\
\hline $\mathrm{Bad} /$ Terrible & 37 & 5.6 & 6 & 16.2 & 31 & 83.8 & \\
\hline \multicolumn{8}{|l|}{ Depressive Symptoms* } \\
\hline Absent & 479 & 75.9 & 286 & 59.7 & 193 & 40.3 & $0.000^{* *}$ \\
\hline Present & 152 & 24.1 & 38 & 25.0 & 114 & 75.0 & \\
\hline
\end{tabular}


Table 1. Body satisfaction according to sociodemographic profile, lifestyle, anthropometry and health conditions among elementary and high school teachers from the State public schools network of Montes Claros, MG, Brazil, 2016.

\begin{tabular}{|c|c|c|c|c|c|c|c|}
\hline \multirow{2}{*}{ Variables } & \multicolumn{2}{|c|}{$n=633(\%)$} & \multicolumn{2}{|c|}{ Satisfied } & \multicolumn{2}{|c|}{ Unsatisfied } & \multirow{2}{*}{$p$} \\
\hline & $n$ & $\%$ & $\mathrm{n}$ & $\%$ & $\mathrm{n}$ & $\%$ & \\
\hline \multicolumn{8}{|c|}{ High Cholesterol } \\
\hline No & 481 & 75.7 & 254 & 52.8 & 227 & 47.2 & $0.190^{* *}$ \\
\hline Yes & 152 & 24.3 & 71 & 46.7 & 81 & 53.8 & \\
\hline \multicolumn{8}{|l|}{ Diabetes* } \\
\hline No & 616 & 97.5 & 315 & 51.1 & 301 & 48.9 & 0.369 \\
\hline Yes & 16 & 2.5 & 10 & 62.5 & 6 & 37.5 & \\
\hline
\end{tabular}

Note: ${ }^{*} n$ total variation, due to information loss; ${ }^{* *}$ significant association $(p<0,20) ; \bar{\chi}( \pm$ SD): estimated mean and Standard Deviation. BMI: Body Mass Index.

In the final multiple model (Table 2), there was a greater chance of dissatisfaction among elderly women who had children. Women who had an unsatisfactory lifestyle had a four-fold chance of dissatisfaction with their body appearance $(O R=4.193)$ compared to those who had a satisfactory lifestyle. In relation to $B M I$, overweight $(O R=2.073)$ or obese $(O R=12.225)$ women had a greater chance of BD when compared to those who had normal BMI. There was also a higher BD among women whose health self-perception was regular $(O R=3.324)$ and poor/very poor $(O R=5.220)$ when compared to women whose health self-perception was excellent/good. And, women with the presence of depressive symptoms had a greater chance $(O R=2.983)$ of $B D$ when compared to those without depressive symptoms.

Table 2. Multiple Regression Model of Body Dissatisfaction among Elementary and High School Teachers from the Montes Claros State Public School System. Montes Claros (MG), Brazil, 2016.

\begin{tabular}{|c|c|c|c|}
\hline Variables & Odds Ratio & $\mathrm{Cl}(95 \%)$ & $p$ \\
\hline Age & 0.946 & $0.923-0.969$ & 0.000 \\
\hline \multicolumn{4}{|l|}{ Children } \\
\hline No & 1 & - & - \\
\hline Yes & 1.992 & $1.215-3.266$ & 0.006 \\
\hline \multicolumn{4}{|l|}{ Lifestyle } \\
\hline Satisfactory & 1 & - & - \\
\hline Inadequate & 4.193 & $1.350-13.023$ & 0.013 \\
\hline \multicolumn{4}{|l|}{ BMI } \\
\hline Normal & 1 & - & - \\
\hline Overweight & 2.073 & $1.349-3.185$ & 0.001 \\
\hline Obese & 12.225 & $6.243-23.940$ & 0.000 \\
\hline \multicolumn{4}{|c|}{ Self-perceived Health } \\
\hline Excellent/Good & 1 & - & - \\
\hline Regular & 3.324 & $2.141-5.158$ & 0.000 \\
\hline $\mathrm{Bad} /$ Terrible & 5.220 & $1.827-14.915$ & 0.002 \\
\hline \multicolumn{4}{|c|}{ Depressive Symptoms } \\
\hline Absent & 1 & - & - \\
\hline Present & 2.983 & $1.810-4.914$ & 0.000 \\
\hline
\end{tabular}

Note: Pseudo R2: 36.8\%; Hosmer and Lemeshow: $8.9 \% ; n=633$

BMI: Body Mass Index; Cl: Confidence Interval. 


\section{DISCUSSION}

The present study showed that almost half of the adult women investigated are dissatisfied with their body image. There was a greater chance of dissatisfaction among women who were older, had children, with unsatisfactory lifestyle, overweight/obese, with poor/very poor self-perception of their health and presence of depressive symptoms.

The high prevalence of BD among this study's women (48.7\%) was consistent with a study conducted in Florianópolis, SC, Brazil that showed a prevalence of dissatisfaction with body image among university students from a public institution, with a $47.3 \%$ dissatisfaction rate [9]. However, higher BD levels were observed in a study conducted in the United States, in which $71.0 \%$ of the study's women reported BD [29].

Another large-scale study carried out in the United States by Mack et al. [30] with 98,387 women over 18 years of age, of different ethnicities, concluded that $70.0 \%$ of them were dissatisfied with their bodies and wanted to lose weight. Alvarenga [5], when evaluating Brazilian female university students, observed that $64.4 \%$ would like to have slimmer bodies than their actual figure. In Brasilia (DF), the prevalence of women dissatisfied with their body image reached $66.2 \%[8]$.

In this study, older women showed greater dissatisfaction with their body image. A previous study with women who practiced muscle-strengthening activities revealed a similar result [8]. In this connection, it is possible to infer that a greater load of aesthetic demands may affect older women, which justifies the selection of thinner figures [5]. On the other hand, Saur and Pasian [31] using the ESIC (Body Image Satisfaction Scale) grouped individuals into different age groups and found no significant differences regarding the level of BD between the groups, suggesting that age does not seem to influence BD self-assessment.

The present study showed that women with children are more dissatisfied with their bodies. Women who had children experienced changes in their body due to the increase in body weight during a relatively short period of time and, therefore, their BD could vary throughout pregnancy and even after the birth of their children [32]. A cross-sectional study, carried out with Japanese women during the second trimester of pregnancy, showed that pregnant women expressed BD and would prefer to be slimmer, although they were of normal weight or even underweight [33].

The results of this investigation revealed that women who had an unsatisfactory lifestyle had a four times greater chance of dissatisfaction with their body appearance $(O R=4.193)$ when compared to those with a satisfactory lifestyle, although studies that investigate the association between lifestyle and body image are not available in the literature.

To describe lifestyle is not an easy task due to the dimensionality of its composition, in addition to inherent factors when measuring a subjective aspect by an objective method [34]; however, important lifestyle elements refer to avoiding smoking, having a good relationship with family and friends, avoiding alcohol consumption, practicing safe sex, controlling stress, in addition to the need to have an optimistic and positive outlook on life [23]. The questionnaire called "Fantastic lifestyle" aims to measure the main elements that characterize a healthy lifestyle [35]. There are other aspects that can be considered in order to enjoy a healthy lifestyle, such as practicing physical activity and a balanced diet [36]. In this regard, we can consider that an inadequate lifestyle can influence the body image of the women investigated due to the risk behaviors adopted. Studies carried out with female university students indicate that BD is increasing because the cult of the body is directly associated 
with the image of power, beauty and social mobility, while technological advances and lack of time contribute to worse lifestyle levels [37-39].

As for anthropometric data, it was observed that overweight women are more dissatisfied with their bodies. This finding is in line with similar studies that, among other aspects, evaluated body satisfaction related to overweight [40]. In contrast, a previous study carried out with Universidade Estadual de Campinas (State University of Campinas) Campinas University's students showed that women were dissatisfied with their body image even though they were in the ideal weight range, which demonstrates the preference for a slim body in order to fit into the social norms [38]. Another study, with a similar result, corroborates the idea of the media influence on women's self-perception of health [41].

Individuals with BD are generally more susceptible to develop eating disorders and to adopt inappropriate behaviors for weight control such as inadequate diets, plastic surgery and abuse of physical exercises [6]. A previous study revealed that young women have a negative self-image, BD and fear of obesity, which lead them to seek weight control initiatives and may lead to appropriate and inappropriate attitudes in social life [18].

The data from the present study showed the highest levels of BD in those women who had the worst health self-perception. Under this perspective, Silva and Baratto [41] stated that the media's performance on the association between health and more aesthetic bodies can be an influencing factor in women's self-perception of health. For Reicher et al. [42], the factors that influence self-perceived health are associated with behavioral, social and demographic aspects. Body Dissatisfaction reflects on self-image and can lead the individual to adopt less appropriate health behaviors with the purpose of acceptance and ideal body [40].

Therefore, it is suggested that self-perceived health is related to body image, which broadens the range of potential causes for a low level of body satisfaction, since dissatisfaction is multifactorial. On the other hand, women with depressive symptoms were the most dissatisfied with their bodies. Based on these data, we can ask: would depression be one of the multifactors that contribute to $\mathrm{BD}$, or would individuals have such dissatisfaction because they are depressed? A study by Almeida et al. [20] evaluated these variables in individuals undergoing bariatric surgery, and there was a clear difference between the depression index before and after the surgery; it was concluded that the improvement in body image after the procedure may have been the cause of such change.

This study has limitations that need to be considered since the cross-sectional design does not allow inferring causality. Despite these limitations, points that increase the validity of the data should be highlighted, with emphasis on the calibration and reach of satisfactory intra- and inter-examiner agreement (weighted Kappa above $81 \%$ and Intraclass Correlation Coefficient above 0.85), robust sample, use of validated instruments and assessment protocols and database auditing. It should be noted that although the sample calculation performed was not specific to represent the female gender; even so, the number of female teachers included in our study ( $n=633$ ) was higher than the minimum required indicated by the sample calculation $(n=630)$; the representativeness and inference power of the investigated female sample were thus maintained. Therefore, the inclusion of only female teachers did not impair the sample's representativeness.

In addition, it is important to point out that OR could overestimate the power of the association [43], since the outcome investigated was frequent (48.7\%). However, this problem only exists when OR is misinterpreted as an estimate of the Prevalence Ratio, which was not the case in our study. It has already been found that the issue is not the use of OR in prevalence studies, but the misinterpretation 
of its meaning, since OR is a measure of association in itself, and is not used solely to estimate other measures of association [44].

The findings also prompt future qualitative research that may integrate different perspectives on the theme, in order to elucidate even more issues regarding the behavior and self-care of women's health and self-esteem.

\section{CONCLUSION}

The results revealed that almost half of the women surveyed reported being dissatisfied with their body image. In particular, women who were older, had children, an unsatisfactory lifestyle, overweight/obesity, poor/very poor self-perception of their health and the presence of depressive symptoms. These results indicate the need for interventions and the implementation of programs related to dissatisfaction with body image. In this perspective, the data from this study can contribute to the implementation of future strategies aimed at better acceptance of the body.

\section{CONTRIBUTIONS}

VEC MOTA contributed to the research data collection, data tabulation and article writing. DS HAIKAL contributed to the design, research data collection, methodological and statistical analyses, data interpretation, writing and final review of the article. TA Magalhães contributed to the design, research data collection and final review of the article. NSS Silva contributed to the research data collection, data tabulation, statistical analysis, data interpretation, writing and final review of the article. RRV Silva contributed to the design, research data collection, writing and final review of the article.

\section{REFERENCES}

1. Poltronieri TS, Tusset C, Gregoletto MLO, Cremonese C. Insatisfação com a imagem corporal e fatores associados em mulheres do sul do Brasil. Ciênc Saúde. 2016;9(3):128-34.

2. Silva DM, Silva RP, Damasceno VO, Werneck FZ, Coelho EF, Soares ER. Percepção subjetiva de alunos do curso de educação física sobre a imagem corporal e variáveis antropométricas de homens adultos. Rev Bras Ciênc Saúde. 2018;22(3):213-20.

3. Rabiepoor S, Jabbari S, Tajil A, Razavi R, Yas A. How Does Obesity, self-efficacy for eating control and body image in women affect each other? Maedica. 2018;13(3):223.

4. Silva GA, Lange ESN. Imagem corporal: a percepção do conceito em indivíduos obesos do sexo feminino. Psicol Argum. 2017;28(60):43-54.

5. Alvarenga MDS, Philippi ST, Lourenço BH, Sato PDM, Scagliusi FB. Insatisfação com a imagem corporal em universitárias brasileiras. J Bras Psiquiatr. 2010;59(1):44-51.

6. Miranda VPN, Filgueiras JF, Neves CM, Teixeira PC, Ferreira MEC. Insatisfação corporal em universitários de diferentes áreas de conhecimento. J Bras Psiquiatr. 2012;61(1):25-32.

7. Pereira ES, Gama EF. Imagem corporal da mulher praticante de exercício físico. HU Rev. 2017;43(1):5-11.

8. Maciel MG, Brum M, Del Bianco GP, Costa LDCF. Imagem corporal e comportamento alimentar entre mulheres em prática de treinamento resistido. RBNE. 2019;13(78):159-66.

9. Albertson ER, Neff KD, Dill-Shackleford KE. Self-compassion and body dissatisfaction in women: A randomized controlled trial of a brief meditation intervention. Mindfulness. 2015;6(3):444-54.

10. Rakhkovskaya LM, Warren CS. Sociocultural and identity predictors of body dissatisfaction in ethnically diverse college women. Bodyimage. 2016;16:32-40. 
11. Nikniaz Z, Mahdavi R, Amiri S, Ostadrahimi A, Nikniaz L. Factors associated with body image dissatisfaction and distortion among Iranian women. Eat Behav. 2016;22:5-9.

12. Freitas CMSM, Lima RBT, Costa AS, Lucena Filho A. O padrão de beleza corporal sobre o corpo feminino mediante o IMC. Rev Bras Educ Fis Esp. 2010;24(3):389-404.

13. Castro MR, Carvalho RS, Ferreira VN, Ferreira MEC. Função e imagem corporal: uma análise a partir do discurso de mulheres submetidas à cirurgia bariátrica. Rev Bras Ciênc Esp. 2010;32(2-4):167-83.

14. Kazarez M, Vaquero-Cristóbal R, Esparza-Ros F. Percepción y distorsión de laimagen corporal en bailarinas españolas em función del curso académico y de laedad. Nutr Hosp. 2018;35(3):661-8.

15. Damasceno VO, Vianna VR, Vianna JM, Lacio M, Lima JRP, Novaes JS. Imagem corporal e corpo ideal. Rev Bras Ciênc Mov. 2008;14(2):81-94.

16. Rentz-Fernandes AR, Silveira-Viana MD, Liz CMD, Andrade A. Autoestima, imagem corporal e depressão de adolescentes em diferentes estados nutricionais. Rev Salud Pública. 2017;19(1):66-72.

17. Miranda VPN, Morais NS, Faria ER, Santos Amorim PR, Marins JCB, Franceschini SDCC, et al. Insatisfação corporal, nível de atividade física e comportamento sedentário em adolescentes do sexo feminino. Rev Paul Pediatr. 2018;36(4):482-90.

18. Del Ciampo LA, Rodrigues DMS, Del Ciampo IRL, Cardoso VC, Bettiol H, Barbieri MA. Percepção corporal e atividade física em uma coorte de adultos jovens brasileiros. Rev Bras Cresc Desenv Hum. 2010;20(3):671-9.

19. Fonseca CC, Chaves ÉDCL, Pereira SS, Barp M, Moreira AM, Nogueira DA. Autoestima e satisfação corporal em idosas praticantes e não praticantes de atividades corporais. J Phys Educ. 2014;25(3):429-39.

20. Almeida SS, Zanatta DP, Rezende FF. Imagem corporal, ansiedade e depressão em pacientes obesos submetidos à cirurgia bariátrica. Estud Psicol. 2012;17(1):153-60.

21. Montes Claros (Minas Gerais). Aspectos gerais 2017. Montes Claros: Portal Prefeituraa de Montes Claros; 2019 [citado 8 ago 2019]. Disponível em: https://portal.montesclaros.mg.gov.br/cidade/aspectos-gerais

22. Associação Brasileira de Empresas de Pesquisa. Critério Padrão de Classificação Econômica Brasil. São Paulo: Associação; 2015 [citado em 3 jun 2019]. Disponível em: http://www.abep.org/Servicos/Download. aspx?id=09

23. Añez CRR, Reis RS, Petroski EL. Versão brasileira do questionário "Estilo de Vida Fantástico": tradução e validação para adultos jovens. Arq Bras Cardiol. 2008;91(2):102-9.

24. World Health Organization. Global status report on noncommunicable diseases. Genebra: Organization; 1995.

25. Paiva CRE, Gaya ACA, Bottaro M, Bezerra RFA. Assessment of the body composition of brazilian boys: the bioimpedence method. Braz J Kinan Hum Perfor. 2002;4(1):37-45.

26. Gorestein C, Andrade LHSG. Inventário de depressão de Beck: propriedades psicométricas da versão em português. Rev Psiq Clin. 1998;25(5):245-50.

27. Ministério da Saúde (Brasil). Vigitel Brasil 2013: vigilância de fatores de risco e proteção para doenças crônicas por inquérito telefônico. Brasília: Ministério; 2014.

28. International Business Machines Corporation. Statistical Package for Social Sciences. version 18.0 [software]. Chicago: IBM; 2016.

29. Jackson K, Janssen I, Appelhans B, Kazlauskaite R, Karavolos K, Dugan S, et al. Body image satisfaction and depression in midlife women: the Study of Women's Health Across the Nation (SWAN). Arch Wom Ment Health. 2014;17(3):177-87.

30. Mack KA, Anderson L, Galuska D, Zablotsky D, Holtzman, D, Ahluwalia I. Health and sociodemographic factors associated with body weight and weight objectives for women: 2000 behavioral risk factor surveillance system. J Wom Health. 2004;13(9):1019-32.

31. Saur AM, Pasian SR. Satisfação com a imagem corporal em adultos de diferentes pesos corporais. Aval Psicol. 2008;7(2):199-209.

32. Meireles JF, Neves CM, Carvalho PH, Ferreira ME. Body dissatisfaction among pregnant women: an integrative review of the literature. Ciên Saúde Colet. 2015;20(7):2091-103.

33. Tsuchiya S, Yasui M, Ohashi K. Assessing body dissatisfaction in Japanese women during the second trimester of pregnancy using a new figure rating scale. Nurs Health Sci. 2019;21:367-74. 
34. Coelho J, Pereira AAJ. Avaliação do estado de vida em adultos jovens universitários. Rev Ges Sus Neg. 2015;3(1):41-50.

35. Canadian Society for Exercise Physiology. The Canadian Physical Activity, Fitness and Lifestyle Appraisal: CSEP's guide to health active living. 2nd ed. Ottawa: CSEF; 2003.

36. Porto EF, Kumpel C, Castro AAM, Oliveira IM, Alfieri FM. Como o estilo de vida tem sido avaliado: revisão sistemática. Acta Fisiátr. 2015;22(4):199-205.

37. Bosi MLM, Luiz RR, Morgado CMC, Costa MLS, Carvalho RJ. Autopercepção da imagem corporal entre estudantes de nutrição: um estudo no município do Rio de Janeiro. J Bras Psiquiatr. 2006;55(1):34-40.

38. Zamai CA, Souza MFV, Jacomo DR. Autopercepção da imagem corporal entre estudantes de fonoaudiologia e educação física/UNICAMP. Resma. 2018;7(2):1-9.

39. Lopes MAM, Paiva AA, Lima SMT, Cruz KJC, Rodrigues GP, Carvalho CMRG. Percepção da imagem corporal e estado nutricional em acadêmicas de nutrição de uma universidade pública. Demetra. 2017;12(1):193-206.

40. Lopes LCC, Ruiz CS, Alves MS, Costa MEA, Mais SER, Marroni D. Autopercepção da imagem corporal entre universitários: uma análise comparativa. RBNE. 2012;6(34):325-32.

41. Silva JS, Baratto I. Análise da percepção, satisfação corporal e conhecimento nutricional entre mulheres praticantes de atividade física. RBNE. 2014;8(46):238-46.

42. Reichert FF, Loch MR, Capilheira MF. Autopercepção de saúde em adolescentes, adultos e idosos. Physis. 2012;17(1):3353-62.

43. Greenland S. Model-based estimation of relative risks and other epidemiologic measures in studies of common outcomes and in case-control studies. Am J Epidemiol. 2004;160(1):301-5.

44. Tian L, Liu K. Re: easy SAS calculations for risk or prevalence ratios and differences. Am J Epidemiol. 2006;163(1):1157-8. 